\title{
Characterization of the enhancement of zero valent iron on microbial azo reduction
}

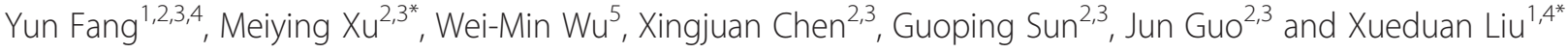

\begin{abstract}
Background: The microbial method for the treatment of azo dye is promising, but the reduction of azo dye is the rate-limiting step. Zero valent iron $\left(\mathrm{Fe}^{0}\right)$ can enhance microbial azo reduction, but the interactions between microbes and $\mathrm{Fe}^{\mathrm{O}}$ and the potential mechanisms of enhancement remain unclear. Here, Shewanella decolorationis S12, a typical azo-reducing bacterium, was used to characterize the enhancement of $\mathrm{Fe}^{0}$ on microbial decolorization.

Results: The results indicated that anaerobic iron corrosion was a key inorganic chemical process for the enhancement of $\mathrm{Fe}^{0}$ on microbial azo reduction, in which $\mathrm{OH}^{-}, \mathrm{H}_{2}$, and $\mathrm{Fe}^{2+}$ were produced. Once $\mathrm{Fe}^{0}$ was added to the microbial azo reduction system, the proper $\mathrm{pH}$ for microbial azo reduction was maintained by $\mathrm{OH}^{-}$, and $\mathrm{H}_{2}$ served as the favored electron donor for azo respiration. Subsequently, the bacterial biomass yield and viability significantly increased. Following the corrosion of $\mathrm{Fe}^{0}$, nanometer-scale Fe precipitates were adsorbed onto cell surfaces and even accumulated inside cells as observed by transmission electron microscope energy dispersive spectroscopy (TEM-EDS).

Conclusions: A conceptual model for $\mathrm{Fe}^{0}$-assisted azo dye reduction by strain $\mathrm{S} 12$ was established to explain the interactions between microbes and $\mathrm{Fe}^{0}$ and the potential mechanisms of enhancement. This model indicates that the enhancement of microbial azo reduction in the presence of $\mathrm{Fe}^{0}$ is mainly due to the stimulation of microbial growth and activity by supplementation with elemental iron and $\mathrm{H}_{2}$ as an additional electron donor. This study has expanded our knowledge of the enhancement of microbial azo reduction by $\mathrm{Fe}^{0}$ and laid a foundation for the development of $\mathrm{Fe}^{0}$-microbial integrated azo dye wastewater treatment technology.
\end{abstract}

Keywords: Azo reduction, Shewanella decolorationis S12, Zero valent iron ( $\mathrm{Fe}^{\mathrm{O}}$ )

\section{Background}

Azo dyes are widely used in the textiles, leather, plastics, cosmetics, and food industries, with a global annual production of more than 5,000 tons. Approximately $10 \%$ of azo products are discharged into the environment, resulting in a negative impact on the environment and human health because most azo dyes are carcinogenic, teratogenic, and highly persistent in the environment [1-3]. Conventional physicochemical methods for treating azo dyes have severe limitations, including incomplete removal, formation of hazardous products, and high operation costs, and biological techniques enable complete mineralization of the azo dye in a more environmentally friendly and cost-

\footnotetext{
* Correspondence: xumy@gdim.cn; xueduanliu@yahoo.com

${ }^{1}$ School of Minerals Processing and Bioengineering, Central South University, 410083 Changsha, China

${ }^{2}$ Guangdong Provincial Key Laboratory of Microbial Culture Collection and Application, Guangdong Institute of Microbiology, 510070 Guangzhou, China Full list of author information is available at the end of the article
}

effective manner $[4,5]$. Azo dyes are not readily degraded by biological methods under aerobic conditions, and thus, they are normally decolorized by reductive cleavage of the azo bonds $(-\mathrm{N}=\mathrm{N}-)$ under anaerobic conditions and then converted to aromatic amines, which are subsequently mineralized aerobically $[6,7]$. The decolorization process is typically rate-limiting, which hinders the biological treatment of azo dyes [8].

Zero valent iron $\left(\mathrm{Fe}^{0}\right)$ can enhance anaerobic microbial azo reduction, but the exact mechanism of $\mathrm{Fe}^{0}$ assisted microbial reduction remains unclear [9-11]. Because azo dyes are decolorized by functional microorganisms, characterizing the $\mathrm{Fe}^{0}$-assisted decolorization of azo dyes using a pure decolorizing bacterium may provide some exact information about the reaction mechanism, and understanding how the microbes interacts with $\mathrm{Fe}^{0}$ will facilitate the elucidation of the mechanisms of enhancement and optimize the biodecolorization process. 
$\mathrm{Fe}^{0}$ is a mild reducer and can chemically reduce several azo dyes under acidic and neutral conditions $[12,13]$. Furthermore, iron is an essential element for microbial survival because the active sites of diverse vital enzymes and proteins contain iron [14,15]. Microorganisms may regulate the iron redox reaction by cellular assimilation of iron. Meanwhile, $\mathrm{Fe}^{0}$ can produce cathodic $\mathrm{H}_{2}$ during the anaerobic corrosion process, and $\mathrm{H}_{2}$ is a favorable electron donor for microbial azo reduction [14,16-18]. According to the following equation

$$
\mathrm{Fe}^{0}+2 \mathrm{H}_{2} \mathrm{O} \rightarrow \mathrm{Fe}^{2+}+\mathrm{H}_{2}+2 \mathrm{OH}^{-}
$$

$\mathrm{Fe}^{2+}, \mathrm{OH}^{-}$, and $\mathrm{H}_{2}$ are the products of the anaerobic corrosion process [19]. The electrode potential of the redox couple $\mathrm{Fe}^{2+} / \mathrm{Fe}^{0}$ is $-0.44 \mathrm{~V}$, and hydrogen production from corrosion exhibits autocatalytic behavior, attaining a maximum rate of $1.9 \mathrm{~mol} \mathrm{~kg}^{-1} \mathrm{~d}^{-1}$ over $2 \mathrm{~d}$ of reaction in a study by Reardon et al. [20]. Based on these knowledge, it is hypothesized that anaerobic $\mathrm{Fe}^{0}$ corrosion may be accelerated in the azo dye biodecolorizing system, then (i) the microenvironmental conditions are altered to produce more favorable redox $/ \mathrm{pH}$ conditions for the growth of microbes; (ii) the additional electron donor $\left(\mathrm{H}_{2}\right)$ from $\mathrm{Fe}^{0}$ corrosion facilitates a greater microbial biomass yield; and (iii) the activity of the azo-reducing bacteria is stimulated by the supplementary elemental iron, resulting in the acceleration of the azo bioreduction.

To test these hypotheses, S. decolorationis S12, an azoreducing bacterium isolated from a textile wastewater treatment system [21,22], was used as a model organism to characterize the enhancement of microbial azo reduction by $\mathrm{Fe}^{0}$ in this study. Specifically, we investigated (i) the effect of $\mathrm{Fe}^{0}$ dosage on the decolorization rate, $\mathrm{pH}$ change, and $\mathrm{H}_{2}$ release to determine whether $\mathrm{Fe}^{0}$ affects azo reduction by strain S12 indirectly; (ii) the morphology of Fe solids outside and inside the cells to determine whether a direct interaction between microbes and $\mathrm{Fe}^{0}$ occurs in the decolorization process; and (iii) the effect of $\mathrm{Fe}^{0}$ addition on the ratio of live versus dead cells and protein contents to determine whether the addition of $\mathrm{Fe}^{0}$ influences the growth and survival ability of strain S12. This study provides new insights into our understanding of the interactions between $\mathrm{Fe}^{0}$ and microbial cells in the decolorization process and lays a foundation for further optimization of $\mathrm{Fe}^{0}$-microbial integrated processes for efficient azo dye treatment.

\section{Methods}

Chemicals, organism, media, and cultivation

Amaranth (Am), a typical water-soluble azo dye, was purchased from Sigma (St. Louis, MO, USA). S. decolorationis
S12 is a rod-shaped, gram-positive facultative bacterium that was isolated from the activated sludge of a textileprinting wastewater treatment plant by Xu et al. [22].

Strain S12 was cultivated by transferring a single colony to a $100-\mathrm{mL}$ conical flask containing $50 \mathrm{~mL}$ of Luria-Bertani medium (10 g/L peptone, $5 \mathrm{~g} / \mathrm{L}$ yeast extract, $10 \mathrm{~g} / \mathrm{L} \mathrm{NaCl}$ ), which was then incubated in a shaking incubator $(160 \mathrm{rpm})$ at $30^{\circ} \mathrm{C}$. The cells were harvested in the middle of exponential growth phase (approximately $8 \mathrm{~h}$ ) by centrifugation, washed twice with phosphate buffer (0.1 M, pH 7.4), and re-suspended in the buffer prior to inoculation. The cells were inoculated into a defined medium ( $\mathrm{pH}$ 7.0) containing $\mathrm{Na}_{2} \mathrm{HPO}_{4}$, $7.64 \mathrm{~g} / \mathrm{L} ; \mathrm{KH}_{2} \mathrm{PO}_{4}, 3.00 \mathrm{~g} / \mathrm{L} ; \mathrm{NH}_{4} \mathrm{Cl}, 0.50 \mathrm{~g} / \mathrm{L} ; \mathrm{NaCl}$, $1.00 \mathrm{~g} / \mathrm{L}$; sodium lactate, $5.00 \mathrm{mM}$; yeast extract, $0.5 \mathrm{~g} / \mathrm{L}$; and amaranth, $1.0 \mathrm{mM}$. The initial cell density was approximately $10^{7} \mathrm{CFU} / \mathrm{ml}$ (the protein mass was approximately $0.023 \mathrm{mg} / \mathrm{mL}$ ). The cells were statically cultivated at $30^{\circ} \mathrm{C}$ in an anaerobic workstation (BugBox, Ruskinn Technologies). Standard anaerobic technique was used throughout the study for anaerobic cultivation as previously described [23]. The medium was prepared by adding concentrated stock solutions containing various medium components in $\mathrm{O}_{2}$-free distilled water. The medium was then bubbled with $\mathrm{N}_{2}$ gas for $10 \mathrm{~min}$ to remove residual air from the head space. All gases used were passed through a $0.2-\mu \mathrm{m}$ filter prior to use. All batch experiments were conducted in $100-\mathrm{mL}$ serum bottles with a culture medium volume of $40 \mathrm{~mL}$ under anaerobic conditions. Three independent experiments with triplicate bacterial samples were performed in each experiment.

Micrometer-sized iron $\left(\mathrm{Fe}^{0}\right)$ particles (mean size of $18.51 \mu \mathrm{m})$ were obtained from Tianjin Guangfu Technology and Development Co., Ltd., China, and were pretreated by rinsing with $1 \mathrm{M} \mathrm{HCl}$ for $3 \mathrm{~min}$, followed by washing with distilled water for $1 \mathrm{~min}$. Different dosages of $\mathrm{Fe}^{0}(0,10,20,30,40,60 \mathrm{mM})$ were added to the defined medium $(40 \mathrm{~mL})$ to examine the effect of $\mathrm{Fe}^{0}$ dosage on the decolorization reaction. The cell-free abiotic control (no strain S12 cells) received $60 \mathrm{mM}$ $\mathrm{Fe}^{0}$. For the other tests, the dosage of $\mathrm{Fe}^{0}$ particles was maintained at $60 \mathrm{mM}$. Before and after decolorization (a reaction period of approximately $30 \mathrm{~h}$ ), the size (hydrodynamic diameter) of the particles was determined using dynamic light scattering in a laser particle size analyzer (Eyetech, Ankersmid, USA).

\section{Growth and activity assays of microbial cells}

Cells were grown in medium with and without $60 \mathrm{mM}$ $\mathrm{Fe}^{0}$ for $12 \mathrm{~h}$ and then collected for cell yield and activity assays, including protein content and live/dead ratio. The protein content was determined by the Coomassie brilliant blue method [24] with slight modification. Briefly, $\mathrm{NaOH}$ solution $(1 \mathrm{M}, 40 \mathrm{~mL})$ was added to the serum 
bottle containing the cell culture in $40 \mathrm{~mL}$ of medium, and the mixture was incubated in a water bath for $10 \mathrm{~min}$ at $95-99^{\circ} \mathrm{C}$ with gentle end-over-end inversion every $2 \mathrm{~min}$. After centrifugation at $12,000 \times g$ for $5 \mathrm{~min}$, the supernatant was collected in a new centrifuge tube at room temperature and reacted with Bradford solution containing 0.01\% (w/v) Coomassie brilliant blue G-250, 4.7\% (w/v) ethanol, and $8.5 \%(\mathrm{w} / \mathrm{v})$ phosphoric acid for $10 \mathrm{~min}$ prior to measuring the absorbance at $595 \mathrm{~nm}$. Bovine serum albumin was used as a protein standard.

A LSM700 laser scanning confocal microscope (Zeiss, Braunschweig, German) was used to examine the activity of $S$. decolorationis $\mathrm{S} 12$ after a 12 -h reaction. A rapid fluorescence staining method using the LIVE/DEAD BacLight $^{\mathrm{tm}}$ Viability Kit (Molecular Probes Inc., Eugene, Oregon, USA) was applied to estimate both the viable and total counts of bacteria according to the manufacturer's recommended protocol.

\section{TEM and SEM analyses}

Transmission electron microscopy (TEM) and scanning electron microscopy (SEM) with energy dispersive X-ray spectroscopy (EDS) were used to observe the structures of the bacterial cells and the iron precipitates. Bacterial cell samples were collected for TEM analysis after a 12$\mathrm{h}$ incubation, and $\mathrm{Fe}^{0}$ samples for SEM analysis were collected after a 30-h incubation. The suspended bacterial cells and $\mathrm{Fe}^{0}$ samples were collected separately. The cell pellet was separated from the medium by centrifugation at $12,000 \times g$ for $5 \mathrm{~min}$, and the pellet (containing cells and $\mathrm{Fe}^{0}$ ) was washed twice with $0.1 \mathrm{M}$ phosphate buffer before fixation in 3\% glutaraldehyde for $5 \mathrm{~h}$. Then, the pellet was washed twice with phosphate buffer and dehydrated in a gradient series of ethanol solutions from 30 to $100 \%$ by incubation at each ethanol concentration for $15 \mathrm{~min}$. For TEM analysis, the sample was treated with acetone and embedded in epoxy resin. Thin sections $(80-90 \mathrm{~nm})$ were cut with a diamond knife mounted on a Leica EM UC6 ultramicrotome and collected on carbon-coated $\mathrm{Cu}$ grids. TEM observation was performed with a JEOL JEM-2010HR TEM at $200 \mathrm{kV}$ or a Hitachi H-7650 TEM at $80 \mathrm{kV}$. For SEM observation, the sample was treated with tert-butanol and then freeze dried. After sputtering with gold, the sample was deposited on the $\mathrm{Cu}$ carrier and observed with either a Hitachi H-3000 N SEM or a FEI Quanta 400 F SEM. The EDS measurement was performed with an Oxford INCA EDX spectrometer coupled with a JEOL JEM-2010HR TEM or an FEI Quanta 400 F SEM.

\section{Chemical analysis and calculation}

The $\mathrm{pH}$ of the solution was measured using a digital multi-parameter 3430 meter (WTW, Germany). The $\mathrm{Fe}^{2+}$ concentration in the aqueous phase was measured using the $\mathrm{HCl}$ extraction ferrozine assay method as previously described [25]. The $\mathrm{H}_{2}$ concentration in the medium after a 12-h reaction was examined by hydrogen microelectrodes (model $\mathrm{H}_{2}-50$, Unisense A/S, Denmark) polarized at $+1000 \mathrm{mV}$.

The decolorization of amaranth was measured by monitoring the decrease in absorbance at a wavelength of $520 \mathrm{~nm}$ with a Beckman DU640 UV/visible spectrophotometer. The decolorization rate and efficiency were calculated as follows:

$$
\begin{aligned}
& \text { Decolorization rate }(\%)=(A-B) / A \times 100 \% \\
& \text { Decolorization efficiency }\left(\mathrm{mmol} \mathrm{L}^{-1} \mathrm{~h}^{-1}\right) \\
& \quad=\text { Decolorization rate } \times C / t
\end{aligned}
$$

where $A$ is the initial absorbance, $B$ is the absorbance after the reaction, $C$ is the initial concentration of amaranth $(1 \mathrm{mM})$, and $t$ is the decolorization reaction time (12 h). All assays were performed in triplicate.

Statistical analysis was conducted with Office Excel 2010, Origin V8.0, and SPSS V17.0 (SPSS Inc. Chicago, IL, USA) software. Treatment $P$ values $<0.05$ were considered significant.

\section{Results and discussion}

\section{Effects of $\mathrm{Fe}^{\mathrm{o}}$ on azo dye decolorization by strain $\mathrm{S} 12$}

To confirm that $\mathrm{Fe}^{0}$ enhanced the anaerobic bioreduction of azo dye, decolorization by strain S12 was performed at six different dosages $(0,10,20,30,40$, and $60 \mathrm{mM})$ of $\mathrm{Fe}^{0}$ at $\mathrm{pH} 7.0$ (Figure 1). The amaranth was completely decolorized in $30 \mathrm{~h}$, except in the treatment without strain S12 cells, suggesting that strain S12 was the major azo reducer and that no observable direct reaction between $\mathrm{Fe}^{0}$ and amaranth occurred. In the presence of increasing doses of $\mathrm{Fe}^{0}$, the complete decolorization time for strain S12 rapidly reduced from 27 to $12 \mathrm{~h}$, and the decolorization efficiency increased from 0.049 to $0.083 \mathrm{mmol} \mathrm{L}^{-1} \mathrm{~h}^{-1}$ (Figure 1). In addition, the decolorization efficiencies of the $\mathrm{Fe}^{0}$-added systems were much higher than those of the $\mathrm{Fe}^{0}$-free systems $\left(0.035 \mathrm{mmol} \mathrm{L}^{-1} \mathrm{~h}^{-1}\right)$, demonstrating that the addition of $\mathrm{Fe}^{0}$ enhanced the biodecolorization of azo dyes. This phenomenon might be attributable to the $\mathrm{H}_{2}$ supply from the cathodic corrosion of $\mathrm{Fe}^{0}$. Based on Equation (1), $\mathrm{H}_{2}$ is generated during the anaerobic corrosion of $\mathrm{Fe}^{0}$.

To determine if the $\mathrm{H}_{2}$ evolved from $\mathrm{Fe}^{0}$ can serve as an electron donor for strain S12 during the decolorization process, the concentration of $\mathrm{H}_{2}$ in the experimental systems after 12-h reactions with different $\mathrm{Fe}^{0}$ dosages was determined. As shown in Figure $1 \mathrm{~b}$, the $\mathrm{H}_{2}$ concentration increased with $\mathrm{Fe}^{0}$ dosage in both the presence and absence of strain S12 (from 36 to $93 \mu \mathrm{mol} \mathrm{L}{ }^{-1}$ and from 129 to $148 \mu \mathrm{mol} \mathrm{L}{ }^{-1}$, respectively), indicating that $\mathrm{H}_{2}$ was generated from the anaerobic corrosion of $\mathrm{Fe}^{0}$. However, the $\mathrm{H}_{2}$ 


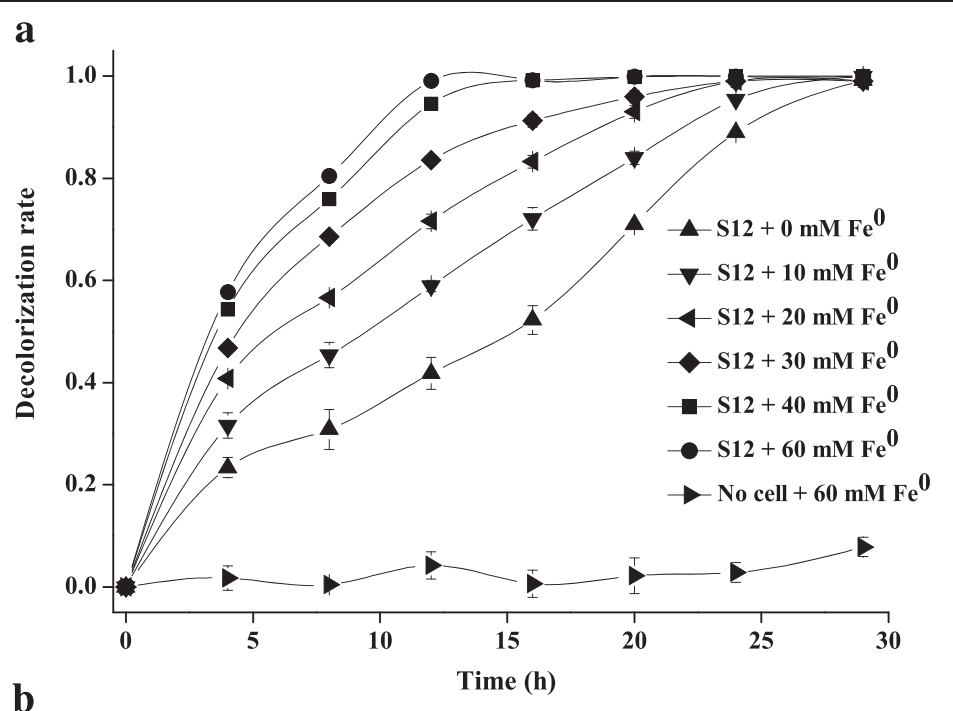

b

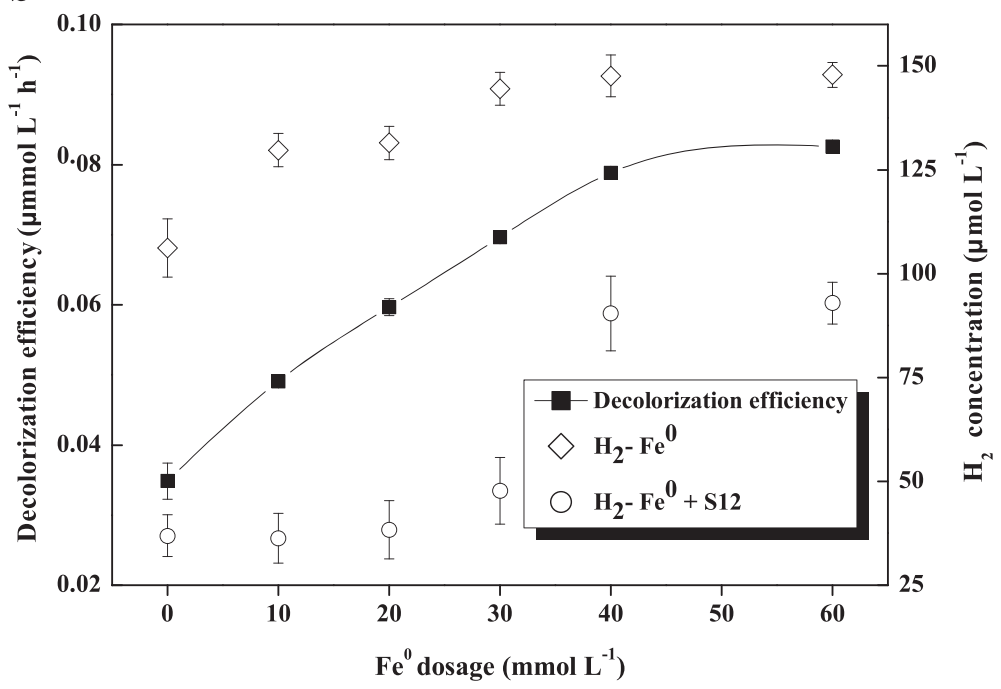

Figure 1 Effect of $\mathrm{Fe}^{0}$ dosage on the decolorization of azo dyes by S. decolorationis S12. (a) The time course of the decolorization rate at different Fe dosages. (b) Decolorization efficiency and $\mathrm{H}_{2}$ concentration at different $\mathrm{Fe}^{0}$ dosages after a 12-h reaction.

concentrations in the presence of strain $\mathrm{S} 12$ were significantly lower than those measured in the cell-free tests $(P<$ 0.001 ), suggesting that the produced $\mathrm{H}_{2}$ was consumed as an electron donor by strain S12 during azo reduction. In addition, as shown in Figure $1 \mathrm{~b}$, the dosage of $\mathrm{Fe}^{0}$ was a rate-limiting parameter for azo reduction when the dosage of $\mathrm{Fe}^{0}$ was less than $40 \mathrm{mM}$, which could be due to the limited $\mathrm{H}_{2}$ supply for strain S12. However, when the dosage of $\mathrm{Fe}^{0}$ was greater than $40 \mathrm{mM}$, the supply of $\mathrm{H}_{2}$ became adequate, and the decolorization efficiency reached a steady state. This study thus confirmed the presence of a dosage threshold for $\mathrm{Fe}^{0}(40 \mathrm{mM})$ for strain $\mathrm{S} 12$ in azo reduction. Previous study of the effect of $\mathrm{Fe}^{0}$ dosage on hexavalent chromium and carbon tetrachloride removal also reported a dosage threshold for $\mathrm{Fe}^{0}$ due to the $\mathrm{H}_{2}$ supply [26].

Furthermore, we also measured the $\mathrm{Fe}^{2+}$ concentrations in the absence and presence of strain S12 cells in the presence of $60 \mathrm{mM} \mathrm{Fe}{ }^{0}$ (no rate limitation of azo reduction was observed at this dosage, as described above) because $\mathrm{Fe}^{2+}$ is one of the products of anaerobic $\mathrm{Fe}^{0}$ corrosion. After a 30-h incubation, the $\mathrm{Fe}^{2+}$ concentration in the experiments with strain S12 was $13.0 \pm 0.5 \mu \mathrm{mol} \mathrm{L} \mathrm{L}^{-1}$, which was significantly higher than that of the abiotic control $\left(2.1 \pm 0.1 \mu \mathrm{mol} \mathrm{L}^{-1}\right)(P=0.03)$, suggesting that strain $\mathrm{S} 12$ promoted the dissolution of $\mathrm{Fe}^{0}$ particles. The same phenomenon was also observed by De Windt et al. [27] for anoxic $\mathrm{Fe}^{0}$ corrosion coupled with nitrate reduction by $S$. oneidensis MR-1. The mechanism of $\mathrm{Fe}^{0}$ consumption remains unclear. There were two likely explanations: (i) the consumption of $\mathrm{H}_{2}$ released from the $\mathrm{Fe}^{0}$ surface by strain S12 allowed the reaction described in Equation (1) to occur and shift to the right, or (ii) strain $\mathrm{S} 12$ reacted with $\mathrm{Fe}^{0}$ directly (such as from the uptake of iron discussed below) and accelerated the transformation of iron. The data in this 
study indicate that both explanations are correct and complementary, but more work is needed to clarify the exact mechanism.

To further examine the changes in the microenvironment around strain $\mathrm{S} 12$ and $\mathrm{Fe}^{0}$, we detected $\mathrm{pH}$ changes during the biodecolorization process in the absence and presence of $60 \mathrm{mM} \mathrm{Fe}{ }^{0}$ conditions with an initial strain S12 cells of $10^{7} \mathrm{CFU} / \mathrm{ml}$ (Figure 2). Generally, the $\mathrm{pH}$ value decreased in the decolorization process both in the absence and presence of $\mathrm{Fe}^{0}$ conditions, with the lowest $\mathrm{pH}$ values of 6.07 and 6.25 at $24 \mathrm{~h}$, respectively. This decrease in $\mathrm{pH}$ is likely due to the production of acetate by lactate oxidation as well as proton release during azo reduction $[28,29]$. Notably, higher $\mathrm{pH}$ values were observed in the systems with $\mathrm{Fe}^{0}$ than in the $\mathrm{Fe}^{0}$-free tests $(P=0.047)$, which could be due to a buffering effect of $\mathrm{OH}^{-}$from the corrosion of $\mathrm{Fe}^{0}$ based on Equation (1). Slight changes in the microenvironmental $\mathrm{pH}$ around the cells can lead to variations in the activity and stability of enzymes and proteins (such as azoreductase) participating in growth and decolorization [30,31], implying that the improved $\mathrm{pH}$ buffer capability of the $\mathrm{Fe}^{0}$-microbial system may also contribute to enhance azo reduction. Similar results have been reported in other $\mathrm{Fe}^{0}$-assisted biodecolorization studies [11].

\section{Shifts in the size distribution pattern of $\mathrm{Fe}^{0}$ particles during biodecolorization}

To measure the consumption of $\mathrm{Fe}^{0}$ during biodecolorization, the change in the size distribution of the $\mathrm{Fe}^{0}$ particles before and after decolorization was characterized using dynamic light scattering (DLS) in the systems inoculated with strain $\mathrm{S} 12$ and $60 \mathrm{mM} \mathrm{Fe}^{0}$ at $\mathrm{pH} 7.0$ (Figure 3). The percentages of small-sized $(<9 \mu \mathrm{m})$ and large-sized $(43-70 \mu \mathrm{m})$ iron particles

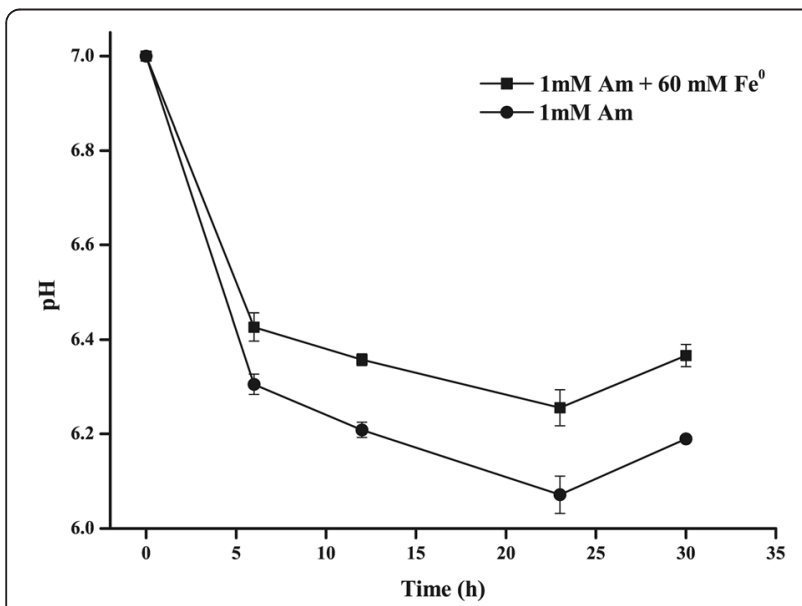

Figure $\mathbf{2}$ Changes in $\mathrm{pH}$ during the biodecolorization process with/without $\mathrm{Fe}^{0}$.

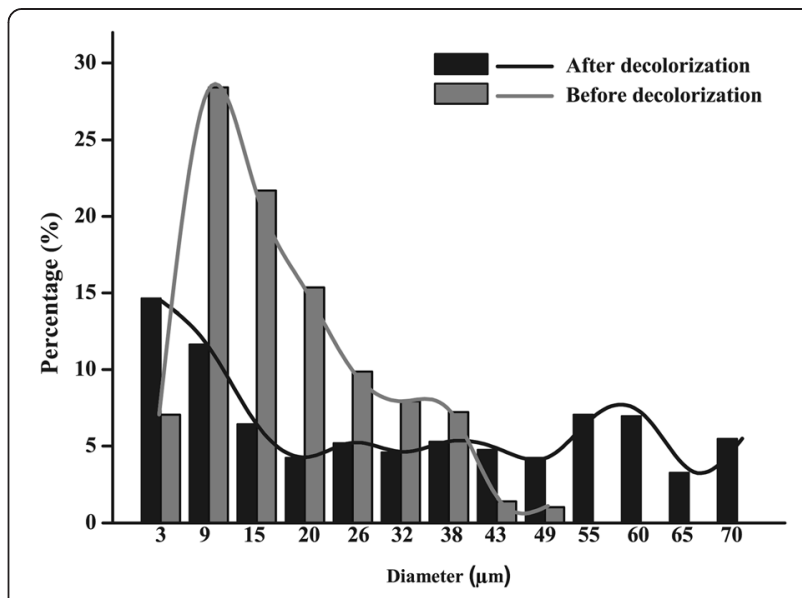

Figure 3 Shifts in the size distribution pattern of the $\mathrm{Fe}^{0}$ particles during the biodecolorization process.

dramatically increased from $7.06 \%$ to $17.47 \%$ and $2.44 \%$ to $37.89 \%$, respectively, while the percentage of medium-sized particles $(9-43 \mu \mathrm{m})$ decreased from $90.50 \%$ to $44.62 \%$ after decolorization. This trend was consistent with the SEM analysis of the particles, which revealed that after a $30-\mathrm{h}$ biological azo reduction, the medium-sized particles with rough surfaces disappeared, and the large-sized particles with smooth surfaces formed clusters (Additional file 1: Figure S1a and Additional file 1: Figure S1b). The surfaces of the $\mathrm{Fe}^{0}$ clusters were further analyzed by EDS, and $\mathrm{Fe}, \mathrm{O}, \mathrm{P}$, and $\mathrm{C}$ were detected as the primary elements (Additional file 1: Figure S1c). According to Equation (1), this result may be due to the formation of ferrous iron precipitates (e.g., $\mathrm{Fe}(\mathrm{OH})_{2}, \mathrm{Fe}_{3}\left(\mathrm{PO}_{4}\right)_{2}$, and $\left.\mathrm{FeCO}_{3}\right)$ that attached to the surface of $\mathrm{Fe}^{0}[32,33]$. These observations confirmed that partially solid $\mathrm{Fe}^{0}$ was consumed during the biodecolorization process.

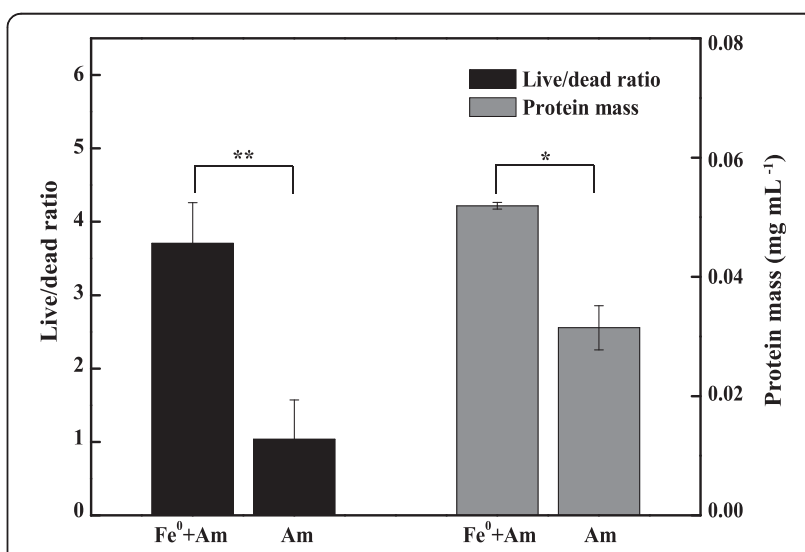

Figure 4 Live/dead ratios and protein masses of bacteria with/without $\mathrm{Fe}^{0}$. For the T-test, ${ }^{*}, P$ value $<0.05 ; * *, P$ value $<0.01$. 


\section{Effects of $\mathrm{Fe}^{0}$ on cell morphology and viability}

We observed that the growth and viability of strain S12 were affected by added $\mathrm{Fe}^{0}$, and we investigated the mechanism by which $\mathrm{Fe}^{0}$ significantly promoted azo reduction. To evaluate cell growth, we measured the biomass yield (i.e., the protein mass) in the presence of $60 \mathrm{mM} \mathrm{Fe}{ }^{0}$ and in the $\mathrm{Fe}^{0}$-free control after cultivation for $12 \mathrm{~h}$. The protein mass in the $\mathrm{Fe}^{0}$-supplemented culture was nearly twice more than that in the culture without $\mathrm{Fe}^{0}$, indicating that added $\mathrm{Fe}^{0}$ can promote the growth of strain S12 $(P<0.05)$ (Figure 4$)$. As an additional electron donor provided by $\mathrm{Fe}^{0}$ corrosion, $\mathrm{H}_{2}$ likely contributed to this growth promotion. The bacterial cell morphology and viability after incubation with and without $\mathrm{Fe}^{0}(60 \mathrm{mM})$ for $12 \mathrm{~h}$ were evaluated by CLSM and TEM. CLSM analysis revealed more live (green) cells in the presence of $\mathrm{Fe}^{0}$ than in a

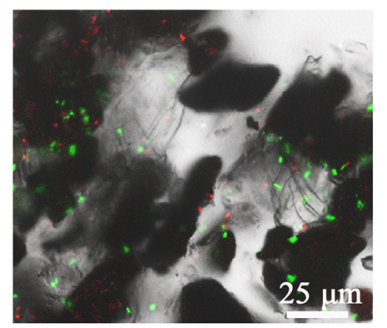

b

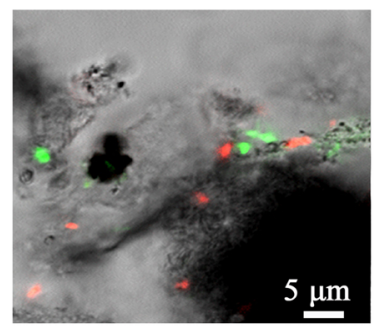

d
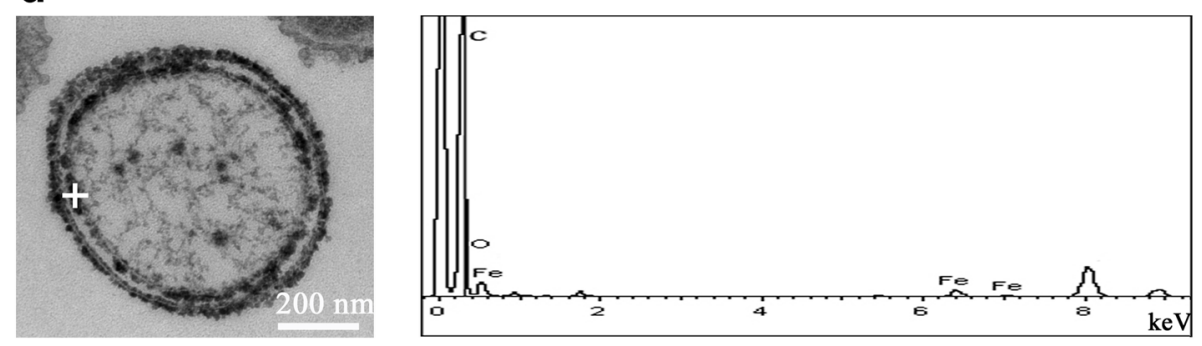

e
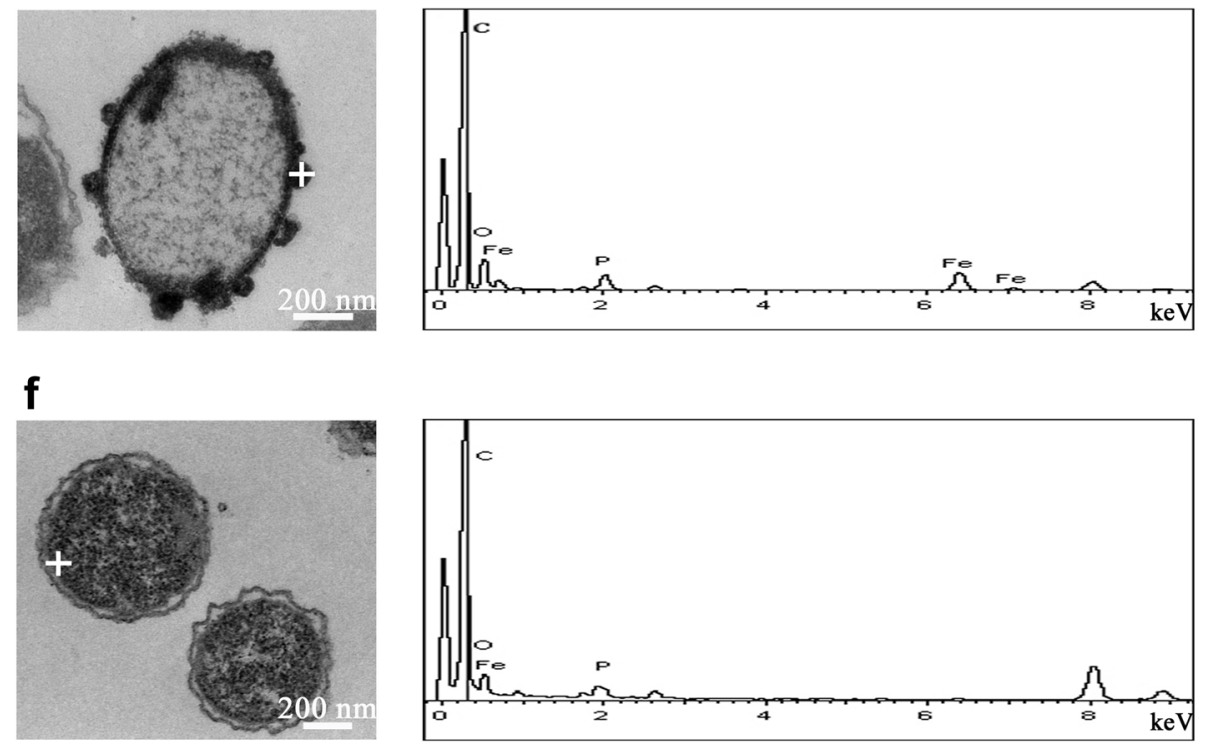

Figure 5 Laser scanning confocal microscope (LSCM) and transmission electron microscopy/energy dispersive X-ray spectroscopy (TEM/EDS) analysis of strain S12 cells. (a) and (b): LSCM images of cells after biodecolorization for $12 \mathrm{~h}$ with $60 \mathrm{mM} \mathrm{Fe} \mathrm{e}^{0}$. The red point represents dead cells, and the green point represents live cells. The iron particles are indicated in black. (c): LSCM image of cells after biodecolorization without Fe ${ }^{0}$. (d) and (e): TEM images and EDS profiles of cells after biodecolorization for $12 \mathrm{~h}$ with $60 \mathrm{mM} \mathrm{Fe}$, showing the presence of iron precipitates inside and outside the cell membrane. (f): TEM images and EDS profiles of cells after biodecolorization without $\mathrm{Fe}^{0}$. The white cross is the site of EDS analysis. The white short line is a scale bar, and the corresponding length is on the top of the scale bar. 
the control (Figure 5a versus Figure 5c). The live/dead ratio of strain $\mathrm{S} 12$ in the $\mathrm{Fe}^{0}$ culture was approximately 3.5 -fold higher than that in the culture without $\mathrm{Fe}^{0}(P<0.01)$, indicating that the presence of $\mathrm{Fe}^{0}$ was beneficial for maintaining cell viability (Figure 4). CLSM also revealed that strain $\mathrm{S} 12$ cells were attached to the surfaces of the micro-scale $\mathrm{Fe}^{0}$ particles (Figure 5a,b), suggesting that strain S12 decolorized azo dyes in both the aqueous and solid phases. Bacterial cell appendages (e.g., the flagella and pili), which were observed in strain S12 (Additional file 1: Figure S2) and confirmed by the genome sequence [34], played an important role in adhesion to the micro-scale $\mathrm{Fe}^{0}$ particles. Other Shewanella spp., such as S. alga, S. putrefaciens and S. oneidensis, also grow adhering to iron minerals [35-37].

The TEM/EDS images demonstrated differences in cell morphology in the $\mathrm{Fe}^{0}$-supplemented culture (Figure 5d,e) and the control (Figure 5f). In the $\mathrm{Fe}^{0}$-supplemented culture, extracellular and/or intracellular fine-grained Fe precipitates or clusters formed outside and/or inside the cell membrane (with mean sizes of $80.52 \pm 15.82 \mathrm{~nm}$ and $25.90 \pm 6.53 \mathrm{~nm}$, respectively) (Figure 5d,e). These results indicated direct interactions between $\mathrm{Fe}^{0}$ and strain S12, providing good evidences for microbial-driven biogeochemical cycling. These direct interactions promoted the transformation of iron as well as the removal of contaminants. First, for contaminant removal, Fe precipitates provided more Fe sources for the synthesis of enzymes and thus enhanced microbial activity. Elemental iron assimilated by strain S12 was an active ingredient for multiple dehydrogenases and hydrogenases (such as [Fe-S] cluster-containing lactate dehydrogenase and $[\mathrm{Ni}-\mathrm{Fe}]$ and $[\mathrm{Fe}-\mathrm{Fe}]$ catalytic site-containing hydrogenases), ensuring higher cell physiological and azoreductive activities [14,34,38]. Second, strain $\mathrm{S} 12$ cells, which were attached to the surface of $\mathrm{Fe}^{0}$, coupled the consumption of $\mathrm{H}_{2}$ (released from $\mathrm{Fe}^{0}$ corrosion) and the reduction of azo dye by azo respiration. For iron transformation, the process included several steps as follows: (i) $\mathrm{Fe}^{2+}$ released from $\mathrm{Fe}^{0}$ corrosion and reversibly adhered to the surface of $\mathrm{Fe}^{0}$ or strain $\mathrm{S} 12$ cells; (ii) $\mathrm{Fe}^{2+}$-containing precipitates formed (e.g., $\mathrm{Fe}(\mathrm{OH})_{2}$, $\left.\mathrm{Fe}_{3}\left(\mathrm{PO}_{4}\right)_{2}, \mathrm{FeCO}_{3}\right)$ when anions presented, and (iii) the small size and high surface-to-volume ratio of fine-grained particles $\left(\mathrm{Fe}^{0}-\mathrm{Fe}^{2+}{ }_{\text {[solid] }}\right)$ enabled significant adsorption of Fe precipitates to the outer membrane of strain S12 cells and the intracellular uptake of Fe precipitates to the cytoplasm of strain $\mathrm{S} 12$ cells. $\mathrm{Fe}^{0}$ corrosion was accelerated because the concentration of $\mathrm{Fe}^{2+}{ }_{\text {[aqueous] }}$ was diluted by

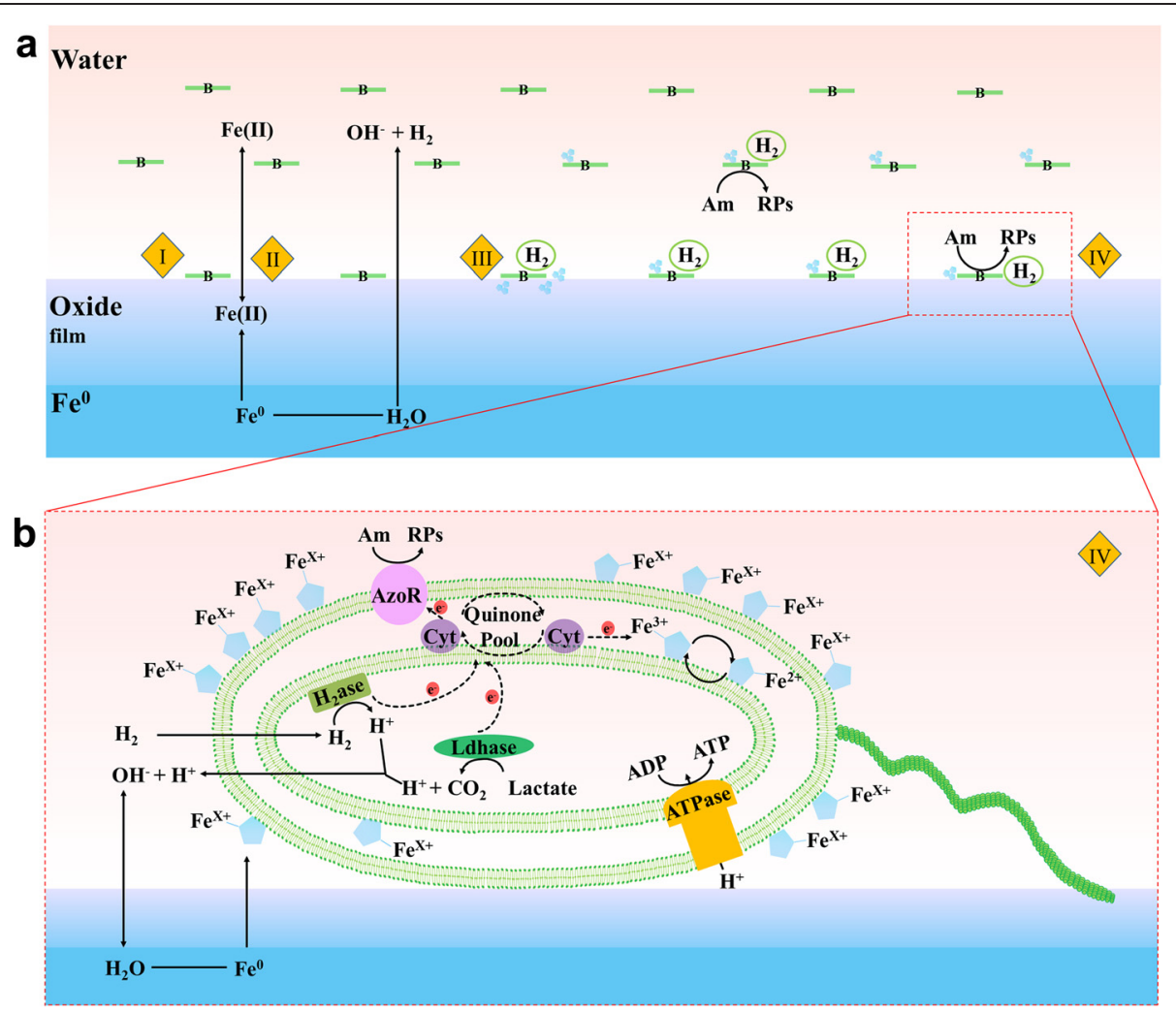

Figure 6 Proposed model for Fe ${ }^{0}$-assisted azo decolorization by S. decolorationis S12. (a) Four sections (I, II, III, and IV) of Fe $\mathrm{O}^{0}$-assisted azo biodecolorization. (b) Magnification of section IV in (a). Note: B = bacterium; Am = amaranth; RPs = reductive products of amaranth; AzoR= azoreductase; $\mathrm{H}_{2}$ ase = hydrogenase; Ldhase = lactate dehydrogenase; $C y t=$ cytochrome protein. 
strain S12 through steps (i) and (iii), suggesting that strain S12 contributed to the transformation of iron, although a quantitative analysis could not be performed here. The biosorption of Fe precipitates has also been observed for other Shewanella spp. [27] and Dehalococcoides spp. [39] involved in $\mathrm{Fe}^{0}$-assisted bioremediation, revealing universal direct interactions between bacteria and minerals during containment removal [40].

\section{Mechanisms of $\mathrm{Fe}^{0}$-assisted biodecolorization}

We propose a conceptual model for the $\mathrm{Fe}^{0}$-assisted azo dye reduction process by $S$. decolorationis S12 (Figure 6). In the model, four sections (I, II, III, and IV) explain the mechanism. In section I, the cells of strain S12, which use the azo bond as the terminal acceptor to complete anaerobic respiration, attach to the surface of the micrometer-scale iron particles. In section II, $\mathrm{Fe}^{0}$ reacts with $\mathrm{H}_{2} \mathrm{O}$ in a neutral-pH, anaerobic environment and produces $\mathrm{H}_{2}$ and $\mathrm{OH}^{-}$. Strain $\mathrm{S} 12$ cells utilize $\mathrm{H}_{2}$ as an electron donor and energy source for growth. In addition, the $\mathrm{OH}^{-}$generated from $\mathrm{Fe}^{0}$ erosion neutralizes the $\mathrm{H}^{+}$released from bacterial metabolism, maintaining the proper $\mathrm{pH}$ for microbial growth. In section III, the strain S12 cells accelerate the dissolution of iron particles due to the consumption of $\mathrm{H}_{2}$, resulting in the generation of nanometer-scale particles and a higher concentration of $\mathrm{Fe}^{2+}$. In section IV, nanometer-scale Fe precipitates adsorb to the surface of the outer membranes and are transported inside the strain S12 cells, improving cell growth and maintenance of viability. The cellular physiological analyses in this study suggest that the addition of $\mathrm{Fe}^{0}$ enhances protein content and bacterial activity. Potential functional proteins and pathways for bacterial azo respiration in the presence of $\mathrm{Fe}^{0}$ are shown in Figure 6b, although further work is needed to verify their involvement.

\section{Conclusions}

The results of batch experiments of azo decolorization by combining the use of $\mathrm{Fe}^{0}$ and the azo-reducing bacterium S. decolorationis strain S12 expanded our knowledge of the enhancement of microbial azo reduction by $\mathrm{Fe}^{0}$. A conceptual model for $\mathrm{Fe}^{0}$-assisted microbial azo reduction was established based on the direct and indirect interactions between microbes and $\mathrm{Fe}^{0}$ after characterizing the changes in the morphology of the $\mathrm{Fe}^{0}$ particles, the physiological activities of the bacteria, and the physicochemical properties of the azo reduction system. This model will facilitate the development of azo dye remediation technology. However, to further elucidate the mechanisms underlying these processes, transcriptomic and proteomic analyses should be performed to track the dynamics and adaptive responses of strain $\mathrm{S} 12$ during $\mathrm{Fe}^{0}$-assisted azo reduction processes.

\section{Additional file}

Additional file 1: Figure S1. Scanning electron microscope/energy dispersive X-ray spectroscopy (SEM/EDS) analysis of the iron particles. (a) Iron particles before biodecolorization. (b) Iron particles after biodecolorization for $30 \mathrm{~h}$. The yellow cross is the site (containing the slice structure) of EDS analysis. (c) The EDS profile of the slice structure on the iron particle surface after biodecolorization. In (a) and (b), the white short line is a scale bar, and the corresponding length is on the top of the scale bar. Figure S2. Transmission electron microscopy (TEM) image of S. decolorationis S12 with a flagellum. The white short line is a scale bar, and the corresponding length is on the top of the scale bar. The white arrow indicates a flagellum on the polar surface of the S. decolorationis S12 cell.

\section{Competing interests}

The authors declare that they have no competing interests.

\section{Authors' contributions}

YF, MX, and XC performed the research and analyzed the data. GS, JG, XL participated in the coordination of the study. YF, MX, and WW wrote the paper. All authors read and approved the final manuscript.

\section{Acknowledgments}

We thank Yinghua Cen for the suggestions during manuscript preparation. This research was supported by the National Basic Research Program of China (973 Program) (2012CB22307), the National Natural Science Foundation for Outstanding Young Scholars of China (51422803), the National Natural Science Foundation of China (21207019), Guangdong Provincial - Chinese Academy of Sciences Strategic Cooperation Projects (2013B091500081), the Natural Science Foundation of Guangdong, China (2014A030308019), and the Special Fund for Agro-scientific Research in the Public Interest (201503108)

\section{Author details}

${ }^{1}$ School of Minerals Processing and Bioengineering, Central South University, 410083 Changsha, China. ${ }^{2}$ Guangdong Provincial Key Laboratory of Microbial Culture Collection and Application, Guangdong Institute of Microbiology, 510070 Guangzhou, China. ${ }^{3}$ State Key Laboratory of Applied Microbiology Southern China, 510070 Guangzhou, China. ${ }^{4}$ Key Laboratory of Biometallurgy of Ministry of Education, 410083 Changsha, China. ${ }^{5}$ Department of Civil and Environmental Engineering, Center for Sustainable Development and Global Competitiveness, Codiga Resource Recovery Center, Stanford University, Stanford, CA 94305, USA

Received: 12 August 2014 Accepted: 27 March 2015 Published online: 10 April 2015

\section{References}

1. Zollinger $\mathrm{H}$. Color chemistry: syntheses, properties and applications of organic dyes and pigments. New York: VCH; 1991.

2. Selvam K, Swaminathan K, Keo-Sang C. Microbial decolorization of azo dyes and dye industry effluent by Fomes lividus. World J Microbiol Biotechnol. 2003;19:591-3.

3. Chacko JT, Subramaniam K. Enzymatic degradation of azo dyes-a review. Int J Environ Sci. 2011;1:1250-60.

4. Forgacs $E$, Cserhati T, Oros $G$. Removal of synthetic dyes from wastewaters: a review. Environ Int. 2004;30:953-71.

5. Fernández C, Larrechi MS, Callao MP. An analytical overview of processes for removing organic dyes from wastewater effluents. Trends Analyt Chem. 2010;29:1202-11.

6. Jonstrup M, Kumar N, Murto M, Mattiasson B. Sequential anaerobic-aerobic treatment of azo dyes: decolourisation and amine degradability. Desalination. 2011;280:339-46.

7. Yemashova N, Kotova I, Netrusov A, Kalyuzhnyi S. Special traits of decomposition of azo dyes by anaerobic microbial communities. Appl Biochem Microbiol. 2009;45:176-81.

8. Solís M, Solís A, Pérez HI, Manjarrez N, Flores M. Microbial decolouration of azo dyes: a review. Process Biochem. 2012;47:1723-48. 
9. Liu Y, Zhang Y, Quan X, Zhang J, Zhao H, Chen S. Effects of an electric field and zero valent iron on anaerobic treatment of azo dye wastewater and microbial community structures. Bioresour Technol. 2011;102:2578-84.

10. Zhang Y, Liu Y, Jing Y, Zhao Z, Quan X. Steady performance of a zero valent iron packed anaerobic reactor for azo dye wastewater treatment under variable influent quality. J Environ Sci. 2012;24:720-7.

11. Li W, Zhang Y, Zhao J, Yang Y, Zeng RJ, Liu H, et al. Synergetic decolorization of reactive blue 13 by zero-valent iron and anaerobic sludge. Bioresour Technol. 2013;149:38-43.

12. Lin $Y T$, Weng $\mathrm{CH}$, Chen FY. Effective removal of AB24 dye by nano/micro-size zero-valent iron. Sep Purif Technol. 2008;64:26-30.

13. Fan J, Guo Y, Wang J, Fan M. Rapid decolorization of azo dye methyl orange in aqueous solution by nanoscale zerovalent iron particles. J Hazard Mater. 2009;166:904-10.

14. Le Laz S, Kpebe A, Lorquin J, Brugna M, Rousset M. $\mathrm{H}_{2}$-dependent azoreduction by Shewanella oneidensis MR-1: involvement of secreted flavins and both [Ni-Fe] and [Fe-Fe] hydrogenases. Appl Microbiol Biotechnol. 2014;98:2699-707.

15. Andrews SC, Robinson AK, Rodríguez-Quiñones F. Bacterial iron homeostasis. FEMS Microbiol Rev. 2003;27:215-37.

16. Weathers $\sqcup$, Parkin GF, Alvarez PJ. Utilization of cathodic hydrogen as electron donor for chloroform cometabolism by a mixed, methanogenic culture. Environ Sci Technol. 1997:31:880-5.

17. Liu Y, Lowry GV. Effect of particle age ( $\mathrm{Fe}^{\mathrm{O}}$ content) and solution $\mathrm{pH}$ on NZVI reactivity: $\mathrm{H}_{2}$ evolution and TCE dechlorination. Environ Sci Technol. 2006;40:6085-90

18. Hong Y, Chen X, Guo J, Xu Z, Xu M, Sun G. Effects of electron donors and acceptors on anaerobic reduction of azo dyes by Shewanella decolorationis S12. Appl Microbiol Biotechnol. 2007;74:230-8.

19. Noubactep $C$, Caré $S$, Crane R. Nanoscale metallic iron for environmental remediation: prospects and limitations. Water Air Soil Poll. 2012;223:1363-82.

20. Reardon EJ, Fagan R, Vogan JL, Przepiora A. Anaerobic corrosion reaction kinetics of nanosized iron. Environ Sci Technol. 2008;42:2420-5.

21. Xu M, Guo J, Kong X, Chen X, Sun G. Fe (III)-enhanced azo reduction by Shewanella decolorationis S12. Appl Microbiol Biotechnol. 2007;74:1342-9.

22. Xu M, Guo J, Cen Y, Zhong X, Cao W, Sun G. Shewanella decolorationis sp. nov., a dye-decolorizing bacterium isolated from activated sludge of a waste-water treatment plant. Int J Syst Evol Microbiol. 2005:55:363-8.

23. Hong Y, Xu M, Guo J, Xu Z, Chen X, Sun G. Respiration and growth of Shewanella decolorationis S12 with an azo compound as the sole electron acceptor. Appl Environ Microbiol. 2007;73:64-72.

24. Bradford MM. A rapid and sensitive method for the quantitation of microgram quantities of protein utilizing the principle of protein-dye binding. Anal Biochem. 1976;72:248-54.

25. Lovley DR, Phillips EJ. Novel mode of microbial energy metabolism: organic carbon oxidation coupled to dissimilatory reduction of iron or manganese. Appl Environ Microbiol. 1988;54:1472-80.

26. Fernandez-Sanchez JM, Sawvel EJ, Alvarez PJ. Effect of Fe $\mathrm{e}^{0}$ quantity on the efficiency of integrated microbial-Fe $\mathrm{F}^{0}$ treatment processes. Chemosphere. 2004;54:823-9.

27. De Windt W, Boon N, Siciliano SD, Verstraete W. Cell density related $\mathrm{H}_{2}$ consumption in relation to anoxic $\mathrm{Fe}(0)$ corrosion and precipitation of corrosion products by Shewanella oneidensis MR-1. Environ Microbiol. 2003;5:1192-202

28. Lanthier M, Gregory KB, Lovley DR. Growth with high planktonic biomass in Shewanella oneidensis fuel cells. FEMS Microbiol Lett. 2008;278:29-35.

29. Yang Y, Guo J, Sun G, Xu M. Characterizing the snorkeling respiration and growth of Shewanella decolorationis S12. Bioresour Technol. 2013;128:472-8.

30. Yang XQ, Zhao XX, Liu CY, Zheng Y, Qian SJ. Decolorization of azo, triphenylmethane and anthraquinone dyes by a newly isolated Trametes sp. SQ01 and its laccase. Process Biochem. 2009;44:1185-9.

31. Yang Y, Lu L, Gao F, Zhao Y. Characterization of an efficient catalytic and organic solvent-tolerant azoreductase toward methyl red from Shewanella oneidensis MR-1. Environ Sci Pollut Res. 2013;20:3232-9.

32. Zhang W. Nanoscale iron particles for environmental remediation: an overview. J Nanopart Res. 2003:5:323-32.

33. Noubactep C. A critical review on the process of contaminant removal in $\mathrm{Fe}^{\mathrm{O}}-\mathrm{H}_{2} \mathrm{O}$ systems. Environ Technol. 2008;29:909-20.

34. Xu M, Fang Y, Liu J, Chen X, Sun G, Guo J, et al. Draft genome sequence of Shewanella decolorationis S12, a dye-degrading bacterium isolated from a wastewater treatment plant. Genome Announc. 2013;1:e00993-00913.
35. Shin $\mathrm{H}$, Singhal N, Park J. Regeneration of iron for trichloroethylene reduction by Shewanella alga BrY. Chemosphere. 2007;68:1129-34.

36. Grantham MC, Dove PM. Investigation of bacterial-mineral interactions using Fluid Tapping Mode ${ }^{T M}$ Atomic Force Microscopy. Geochim Cosmochim Acta. 1996;60:2473-80.

37. Neal AL, Bank TL, Hochella MF, Rosso KM. Cell adhesion of Shewanella oneidensis to iron oxide minerals: Effect of different single crystal faces. Geochem Trans. 2005;6:77-84.

38. Pinchuk GE, Rodionov DA, Yang C, Li X, Osterman AL, Dervyn E, et al. Genomic reconstruction of Shewanella oneidensis MR-1 metabolism reveals a previously uncharacterized machinery for lactate utilization. Proc Natl Acad Sci U S A. 2009;106:2874-9.

39. Xiu Z, Jin Z, Li T, Mahendra S, Lowry GV, Alvarez PJ. Effects of nano-scale zero-valent iron particles on a mixed culture dechlorinating trichloroethylene. Bioresour Technol. 2010;101:1141-6.

40. Gadd GM. Metals, minerals and microbes: geomicrobiology and bioremediation. Microbiology. 2010;156:609-43.

\section{Submit your next manuscript to BioMed Central and take full advantage of:}

- Convenient online submission

- Thorough peer review

- No space constraints or color figure charges

- Immediate publication on acceptance

- Inclusion in PubMed, CAS, Scopus and Google Scholar

- Research which is freely available for redistribution 